\title{
Dharmottara's Interpretation of the Causelessness of Destruction
}

\author{
SAKAI Masamichi
}

\section{Introduction}

It goes without saying that the new proof of momentariness systematized by Dharmak${ }_{i r t i}{ }^{1)}$ (ca.600-660) determines the direction of the later development of the proof of momentariness. ${ }^{2)}$ In this proof, the existent (sat) is defined as being causally efficacious, and thereby the lack of causal efficacy of the non-momentary (aksanika) is deduced, for the way a thing produces an effect is either gradual or simultaneous and the non-momentary can produce its effect neither gradually nor simultaneously. Thus, it is proven by negating the existence of the non-momentary that all that is existent is momentary. Meanwhile, owing to the appearance of the new proof, the traditional proof of momentariness founded upon the causelessness of destruction (vināsasya-ahetutva) was moved outside the mainstream proofs for momentariness. In this traditional proof whose object of application is restricted to the produced ( $k r t a k a)$ and which always requires the impermanence (anityatva) of the produced as its presupposition, it is only possible to infer momentariness of the produced from its impermanence by virtue of the causelessness of destruction. Therefore, in the traditional proof, the ascertainment of the pervasion (vyāptiniścaya) of the property of being produced (krtakatva) by the property of being impermanent (anityatva) is not the topic in the first place. On the contrary, in the new proof not only the momentariness itself, but also the pervasion of the property of being existent (sattva) by the property of being impermanent or being momentary (kṣanikatva) is established. Therefore, from the logical point of view, it may be no exaggeration to say that the appearance of the new proof makes the existence of the traditional proof completely superfluous. In spite of this fact, however, in the actual history of Indian Buddhism, the traditional proof never disappeared. One possible reason for this can be found in the activities of Dharmakirti's successors. For example, Dharmottara (ca.740-800) is engaged in the traditional proof in a unique way. That is, 
he places the causelessness of destruction, which is the very backbone of the traditional proof, in the framework of the new proof and thereby gives it a new function. The aim of this paper is to introduce one interpretation, unique to Dharmottara, of the causelessness of destruction by focusing on the argument that appears in an independent work of his, the Kṣaṇabhangasiddhi (henceforth: KBhS) with the great help of Muktākalaśa's (ca.1000?) commentary the Kșanabhangasiddhivivarana (henceforth: KBhSV).

\section{Objection of the opponent}

In KBhS, Dharmottara's unique interpretation appears in the course of the discussion where he confronts a very distinctive objection of (an) opponent $(\mathrm{s})$. The following is the outline of the opponent's assertion: (1) What the opponent asserts is that the logical reason (hetu) "being existent (sattva)" characterized as having the nature of being causally efficacious, from which the momentariness is inferred, is inconclusive (anaikantika) because the exclusion of this logical reason from the dissimilar (vipaksa) is doubtful. (2) Namely, even the non-momentary can produce an effect gradually by depending on a gradually cooperating cause (sahakärin). Therefore, the non-momentary is causally efficacious and hence can be considered existent. (3) In order to illustrate this theory by an example (drsțānta) of such a cooperating cause, the opponent points to a hammer as a cause of destruction (vinās$a h e t u)$. According to the opponent, there is a certain similarity between the causes of destruction and the cooperating causes that the non-momentary requires when it produces its effect, that is, "to do nothing (akimcitkara) to a material cause (upādāna)." The opponent thinks according to the following schema:

A non-momentary thing as material cause + a cooperating cause $\Rightarrow$ produce an effect

In this case, however, a cooperating cause does not do anything to a material cause, namely, it neither gives superiority in quality (atiśaya) to a material cause nor does it refine $(s a m s-\sqrt{k r}$ ) a material cause so that it produces an effect.

A pot as material cause + a hammer $\Rightarrow$ disappear

In this case, however, a hammer does not do anything to a pot, namely, it neither gives superiority in quality to a material cause nor does it refine a pot so that it disappears.

(4) Moreover, according to the opponent, one must not say that a hammer is not a cause of destruction of a pot because it does not do anything to a pot, because destruction of a pot follows the presence and absence of a hammer. (5) In order to exemplify this theory, the opponent gives a further example, that is, the causal relation between seed and sprout. The 
opponent thinks as follows: Although a seed does not refine a sprout so that it arises, a sprout is subject to the existence and non-existence of a seed. Therefore, a seed can be called the cause of a sprout, in the same way that it can be said: Although a hammer does not refine a pot so that it disappears, destruction of a pot is subject to the existence and non-existence of a hammer. Therefore, a hammer is a cause of destruction. ${ }^{3)}$ Thus, it is proven that just like the fact that a pot disappears in dependence on a hammer, even the non-momentary produces its effect dependent on a cooperating cause. Therefore, the logical reason "being existent" is a pseudo-reason that is inconclusive, for the exclusion from the dissimilar is doubtful. That is the assertion of the opponent.

\section{New function of the causelessness of destruction}

Answering this objection in the KBhS, Dharmottara rebuts this attack of the opponent concerning the logical reason "being existent" by rejecting the cause of destruction as an example of a cooperating cause. Muktākalaśa comments upon this very negation of the cause of destruction by Dharmottara as follows:

In order to prove the logical reason ["being existent"] conclusive, [Dharmottara,] aiming to refute the cause of destruction as the example brought up by the opponent, repeats [the above-mentioned opponent's objection] with the words "as has been said." ... Just as soil in case of the seed of rice, the pot cannot depend on a thing as a cause of destruction. Therefore, a pot is unestablished as the example of [the theory] that a thing as a cooperating cause is, though it does not do anything to a material cause, needed [by it]. Hence, that which is explained by an example (*dārștānta) is unestablished. Therefore, the statement concerning the inconclusiveness [of the logical reason of "being existent"] that even the non-momentary can be an agent [that produces an effect] gradually is pulled up (*uddhrta) ${ }^{4)}$ by its roots (*samülam), and that is the content of this treatise (i.e., $\mathrm{KBhS}$ ) in totality. ${ }^{5 \text { ) }}$

This means that, when Dharmottara negates the cause of destruction as an example of a cooperating cause, his rejecting the cause of destruction is motivated by the special aim of proving that the logical reason "being existent" is conclusive (aikantika). In other words, when Dharmottara negates the cause of destruction as an example and thereby proves it to be unestablished, then the theory explained by this example, that even the non-momentary can produce its effect gradually by depending on a gradually cooperating cause, is also proven to be unestablished, since the example is unestablished (drsștântāsiddha). Accordingly, the critique by the opponent that the logical reason "being existent" is inconclusive 
is invalidated. Thus, this logical reason turns out to be conclusive.

Moreover, Muktākalaśa makes a conclusive remark of Dharmottara's argument to reject the cause of destruction:

With the words "therefore" and so on, [Dharmottara] summarizes the purpose to which the abovementioned [argumentation to reject the cause of destruction] contributes. This kind of rejection of the cause of destruction is [taught] by the former teachers (*pūrvācāryaih), [and it] is taught by another person (*parena, i.e., Dharmakirti) as the principle of the proof of momentariness as follows (*iti): "Since there is no cause of destruction, destruction is connected with [things] on the basis of [their] nature (= PV $1.193 \mathrm{~cd}$ )." However $\left(n i,{ }^{*} t u\right)$, for the author of this treatise (i.e., Dharmottara), the strength [of this kind of rejection of the cause of destruction] should be understood through the very logical reason "being existent," [and this kind of rejection of the cause of destruction] is brought forward [by him], in order to clear away its fault [i.e. the fault that this logical reason should be inconclusive]. ${ }^{6)}$

Here, Muktākalaśa is pointing out the following three important facts: (1) The notion of the causelessness of destruction is ascribed to the former teachers. (2) This traditional notion is formulated by Dharmakirti as the principle of the proof of momentariness in his PV $1.193 \mathrm{~cd}$. (3) For Dharmottara, however, its value and strength should be understood through the very logical reason "being existent." What is striking in this commentary of Muktākalaśa is that he calls Dharmakīrti not a teacher ( $\bar{a} c \bar{a} r y a)$ and so on, but merely "another person (gzhan, *para)."

\section{Conclusion}

As observed above, for Dharmottara the causelessness of destruction has the special role of eradicating the fault that the logical reason "being existent" is inconclusive. Namely, the causelessness of destruction, which is the base constituent of the traditional proof, is included in the system of the new proof and given a new function there, that is, to prove that the logical reason of the new proof is conclusive. However, Dharmottara in his KBhS also takes up the primary function of the causelessness of destruction to infer the momentariness of the produced. Therefore, his unique interpretation of the causelessness of destruction, observed above, indicates one of its aspects in Dharmottara's logical system. In addition, this interpretation is valid only against the opponent's objection in which the cause of destruction is brought up as an example of a cooperating cause, depending on which the non-momentary produces its effect gradually. The very same objection can be 
found in his Pramānaviniścayațikā, second chapter, where Dharmottara states that the causelessness of destruction that has the function of refuting the cause of destruction as an example of a cooperating cause is an assistant (parikara) to the negating valid cognition (bādhakapramāna) which ascertains the pervasion of the property of being existent by the property of being momentary. ${ }^{7)}$ In my opinion, this unique idea of Dharmottara, to interpret the causelessness of destruction in the framework of the new proof, is one of the good examples representing his originality and creativity, which made Prof. Frauwallner call him "der erste buddhistische Logiker nach Dharmakirti." 8)

* I am obliged to Prof. Taiken Kyūma for his valuable comments and suggestions. I am also very grateful to Patrick McAllister who kindly corrected my English.

\title{
Notes
}

1 ) For a detailed analysis of how Dharmakirti systematizes the new proof and what the theoretical and historical background of the new proof is, see Yoshimizu 1999.

2) Cf. Steinkellner 1968: 376. 3 ) The above-mentioned arguments from (1) to (5) appear in KBhS 220,14-221,6. For translations of this passage of the KBhS, see Frauwallner 1935: 237-238, and Tani 1997 (a) : 24. My understanding of the contents of this objection is greatly indebted to Muktākalaśa's commentary. Cf. KBhSV D260a3-260b4; P279b1-280a3.

4) bton pa em.: ston pa DP.

5 ) KBhSV D263a1-3; P283b2-5 (on KBhS 225,7-11).

6) KBhSV D267b5-7; P288a1-3 (on KBhS 228,24-229,10).

7 ) Cf. Sakai forthcoming.

8 ) Cf. Frauwallner 1935: 218.

\begin{abstract}
Abbreviations and literature
D: Derge edition. P: Peking edition. KBhS: Kșanabhangasiddhi (Dharmottara), ed. E. Frauwallner, Frauwallner 1935: 219-237. KBhSV: Kṣanabhangasiddhivivarana, D 4254; P 5752. PV 1: The first chapter of the Pramānavārttika, ed. R. Gnoli, Rome 1960. PVin 2: The second chapter of the Pramānaviniścaya, ed. E. Steinkellner, Beijing-Vienna, 2007. Frauwallner 1935: E. Frauwallner, "Dharmottaras Kṣaṇabhangasiddhih: Text und Übersetzung," WZKM, 42 (1935), 217-258. Tani 1997 (a): "Problems of Interpretation on Dharmottara's "Kṣaṇabhangasiddhi" (1)," Bulletin of Koch National College of Technology, 41 (1997), 19-37 (in Japanese). Sakai forthcoming: M. Sakai, "Śākyabuddhi and Dharmottara on the inference of momentariness based on the absence of external causes of destruction," Proceedings of the Fourth International Dharmakirti Conference, Vienna, August 23-27, 2005. Steinkellner 1968: E. Steinkellner, "Die Entwicklung des kșaṇikatvānumānam bei Dharmakīti," WZKS, 12/13 (1968/69), 361-377. Yoshimizu 1999: Ch. Yoshimizu, "The Development of sattvānumāna from the Refutation of a Permanent Existent in the Sautrāntika Tradition,” WZKS, 43 (1999) , 231-254.
\end{abstract}

〈Key words〉 Dharmottara, Kṣanabhañgasiddhi, Muktākalaśa, Kṣanabhañgasiddhivivarana (Doctoral candidate, University of Vienna) 